\title{
Carmelo Salvatore Asero, La dipendenza sessuale da internet e la sua incidenza in ordine alla capacità consensuale matrimoniale, Lateran University Press, Città del Vaticano 2014, ss. 240
}

DOI: http://dx.doi.org/10.15633/acan.1067

Dysertacja doktorska księdza Carmelo S. Asero dołącza do grona najlepszych prac napisanych na Wydziale Prawa Kanonicznego Instytutu Utriusque Iuris Papieskiego Uniwersytetu Laterańskiego w Rzymie.

Struktura pracy jest typowa dla publikacji o charakterze wyłącznie naukowym, co w pewien sposób zawęża grono potencjalnych odbiorców. Z drugiej zaś strony publikacja jest niezwykle cennym przyczynkiem do rozwoju współczesnej kanonistyki i pogłębienia wiedzy samych prawników, jak i biegłych, zważywszy dodatkowo na pogłębiające się problemy związane z niewłaściwym korzystaniem z łącz internetowych, zwłaszcza przez ludzi młodych.

Wyróżnienie i publikacja książki w serii Corona Lateranense wskazuje, że walory dysertacji nie ograniczają się tylko do próby syntetycznego opracowania tematu uzależnienia od internetu i jego ewentualnego wiążącego wpływu na ważność zgody małżeńskiej. Oprócz oryginalnego przedmiotu pracy na uwagę czytelnika zasługuje wykorzystanie najnowszej literatury, jak również - mająca na względzie szeroki zakres problemu omawianej kwestii - selekcja tych informacji, które pozwoliły na wyciągnięcie właściwych wniosków dotyczących rzeczywistej incydencji uzależnienia od cyberseksu na zdolność nupturientów w przypadku kanonicznego konsensu małżeńskiego.

Mówiąc o możliwym rozwiązaniu problemu zasygnalizowanego w tytule pracy, autor wielokrotnie zaznaczał, że brak orzeczeń Trybunału Roty Rzymskiej w problematyce uzależnienia od różnorodnych form cyberseksu. Taki stan rzeczy niewątpliwie spowodował obligatoryjne użycie ogólnych zasad prawa kanonicznego przy jednoczesnym uwzględnieniu posiadanej - i dość licznie zgromadzonej - jurysprudencji dotyczącej ogólnie pojętych uzależnień.

Autor omówił podjęte zagadnienie w trzech rozdziałach, z których ostatni stanowi próbę jednoznacznej odpowiedzi na pytanie o rzeczywisty związek pomiędzy seksualnym uzależnieniem od internetu i wystarczającą zdolnością podmiotu do właściwej oceny istotnych praw i obowiązków małżeńskich wzajemnie przekazywanych i przyjmowanych (por. kan. 1059, $2^{\circ}$ ).

Rozdział pierwszy w całości poświęcony został chrześcijańskiej antropologii małżeństwa. Autor dokonał syntetycznego, lecz nie powierzchownego studium 
biblijnych fundamentów i przesłanek małżeństwa, odnosząc się szczególnie do jego starotestamentowego i ewangelicznego rozumienia. W dalszej kolejności przeprowadził solidną analizę niektórych elementów tradycyjnej i chrześcijańskiej antropologii oraz etyki seksualnej, tak by ukazać szczególną wartość powyższych zagadnień z punktu widzenia doktryny katolickiej.

Mając na uwadze niezliczoną ilość dostępnej literatury w powyższej kwestii, autor dokonał koniecznej jej selekcji, uwzględniając tylko ten materiał, w którym jasne były chrześcijańskie przesłanki małżeństwa, jak również personalistyczne ujęcie złożonego problemu ludzkiej seksualności przedstawione w dokumentach Soboru Watykańskiego II i późniejszych wypowiedziach Stolicy Apostolskiej.

W drugim rozdziale dysertacji podjęty został temat uzależnień behawioralnych (czynnościowych), których negatywne konsekwencje, w sposób nieunikniony zaburzając wewnętrzne funkcjonowanie jednostki, skutkują stanami cierpienia zauważalnymi we wszystkich wymiarach życia.

Szeroka gama powyższych zaburzeń, z których dla celów metodologicznych pracy został wybrany tylko jeden, zagrażają w znaczny sposób życiu małżonków, jak również osłabiają tworzoną przez nich strukturę rodziny.

Autor, świadomy złożoności problemu, nakreślił kompleksową panoramę dotyczącą zagadnienia wspomnianych zaburzeń, poświęcając szczególna uwagę roli nałogu i uzależnień od seksu w kontekście psychotechnologii (internetu), w celu sformułowania trafnej konkluzji w podjętej kwestii.

Dodatkowym atutem tej części pracy jest końcowa refleksja podkreślająca negatywne skutki wspomnianego uzależnienia na interpersonalne relacje między małżonkami i/lub nupturientami: silny dysonans emocjonalny w przeżywaniu fizycznych aktów miłości przez uzależnionego; snobistyczne poszukiwanie własnej przyjemności w seksie; pomniejszona lub kompletnie zredukowana inicjatywa w sferze aktów seksualnych na rzecz kompulsywnych zachowań online; fantazje i poszukiwania nowych bodźców i form seksu online; banalizowanie seksualnych potrzeb partnera; umniejszanie wartości monogamicznego związku; mniejsze pragnienie potomstwa itd.

Należy stwierdzić widoczną różnicę w języku używanym w dwóch pierwszych rozdziałach, co zdradza, najprawdopodobniej, małą umiejętność płynnego przechodzenia z tematu w temat. Być może to tylko subiektywne wrażenie, jednakże dające o sobie znać w całościowej lekturze.

Dodatkowo ta część pracy została oparta wyłącznie o literaturę włoskojęzyczną, redukując tym samym swój potencjalny walor o osiągnięcia w dziedzinie psychologii i psychoterapii innych niż rodzime autorowi środowisk naukowych. 
Trzeci i ostatni rozdział pracy rozpoczyna dogłębna analiza dwóch ostatnich typologii normatywnych dotyczących niezdolności małżeńskich regulowanych przez ustawodawcę kościelnego w kan. 1095. Do tak konstruktywnego zestawienia problemu autor dołączył refleksję mającą za przedmiot rzeczywistą relację między uzależnieniem od wirtualnego seksu a innymi wadami zgody małżeńskiej (error qualitatis ex kan. 1097, $2^{\circ}$ i dolus ex kan. 1098).

Pierwszorzędnym celem autora było jednak wskazanie sposobu, w jaki tak pojęte uzależnienie może wpływać na discrectio iudicii - w zakresie podstawowych praw i obowiązków matrymonialnych (kan. 1095, 2º - jak również na zdolność podjęcia obligationes matrimonii essentiales, gdzie nałóg jest tożsamy z przyczyną natury psychicznej (kan. 1095, $\left.3^{\circ}\right)$.

Po dogłębnej analizie wypowiedzi doktrynalnych, jak również dostępnego materiału jurysprudencyjnego $\mathrm{w}$ podobnych przypadkach, autor doszedł do wniosku, że nie jest możliwe domniemanie niezdolności uzależnionego od cyberseksu w relacji do wspomnianych norm kodeksowych. Uzależnienie, nawet jeśli uznane za bezspornie ewidentne, może stanowić co najwyżej poszlakę, nie zaś dowód niezdolności $\mathrm{w}$ tym sensie. Ta bowiem powinna być udowodniona przy wykorzystaniu właściwych środków probatoryjnych, zwłaszcza opinii biegłych. Autor podkreślił, że seksualna zależność od internetu, rozumiana jako czynnik determinujący zdolność konsensualną, jest tylko potencjalna i nie może być tożsama z diagnozą biegłego o rzeczywistym istnieniu zaburzenia behawioralnego w tym sensie.

Podobne wnioski odnoszą się do treści kan. 1095, $3^{\circ}$ : sama zależność od internetu może kwalifikować się jako warunek psychicznej niemocy, która może powodować w jednostce niemożliwość podjęcia obowiązków małżeńskich. Co więcej: podmiot jest w stanie pragnąć prawdziwego małżeństwa, jednakże - ze względu na egocentryzm i problemy wynikające z niekontrolowanej sfery afektywno-seksualnej - nie jest zdolny podjąć podstawowych obowiązków małżeńskich.

Jeśli zaśchodzi o implikacje problemu wświetle normy wyrażonej w kan. 1097, 2, autor zwraca uwagę na dwa znaczące elementy: pierwszy polega na dokładnym studium okresu poprzedzającego zawarcie małżeństwa, w którym - w oparciu o inne dane z biografii jednostki - jesteśmy w stanie określić jej zdrowo ułożoną sferę afektywno-seksualną; drugi zaś winien wskazać na spójny związek, jaki osobista historia podmiotu wywiera na sam moment celebracji sakramentu i ewentualnych reakcji osoby w pożyciu za każdym razem, kiedy zostanie odkryty problem. Należy więc niezbędnie określić, że nupturient przed zawarciem małżeństwa chciał, 
directe e principaliter, za bezpośredni przedmiot zgody obrać przymiot uporządkowanej seksualności partnera, której jednak ten nie posiadał.

W odniesieniu do ostatniej hipotezy autor zauważa, że uzależnienie od cyberseksu poważnie narusza wzajemne zaufanie stron. Jest bezspornie jasne, że motywem czyniącym małżeństwo nieważne ex dolo nie jest samo uzależnienie - rozumiane jako anomalia czy aberracja - lecz jego świadome zatajenie i ukrycie.

Na zakończenie należy nadmienić, że stosowanie aparatu krytycznego jest prawidłowe i spełnia wymogi standardowej metodologii naukowej. Bibliografia została uporządkowana zgodnie z przyjętymi zasadami kanonistyki, jednakże - co zostało zauważone - odczuwalny jest zupełny brak odniesień do doktryny innej niż włoska.

Podsumowując, należy stwierdzić, że niniejsza praca stanowi znaczący krok naprzód w rozumieniu współczesnych problemów, dotyczących zwłaszcza ludzi młodych, u których z coraz większą częstotliwością diagnozuje się różne formy uzależnień. Takie osoby Mario Francesco Pompeda definiuje jako „jednostki słabe”, zwłaszcza w obliczu małżeństwa rozumianego nie tylko jako wybór drogi życia, lecz przede wszystkim jako ustawiczne zadanie angażujące całą ludzką egzystencję.

Przemysław Michowicz OFMConv 